\title{
Prediksi Jumlah Produksi Barang pada UD. Sari Murni Menggunakan Metode Fuzzy Tsukamoto
}

\author{
Vivi Aida Fitria ${ }^{1, \text { a) }}$, Putri Ade Wasna ${ }^{1, b)}$ \\ ${ }^{1}$ STMIK Asia Malang \\ Email: a)viviaidafitria@gmail.com, ${ }^{\text {b) }}$ putri.wasna@gmail.com
}

\begin{abstract}
UD. Sari Murni, known as Jenang Lasimun, is a trading company that sell specialty foods, namely jenang or dodol. This is a must-have food for a celebration or as a souvenir. The human resources in these small and medium enterprises were required to use a computerized system in order to fill the market needs. The problem of UD. Sari Murni is about the uncertainty of consumer demands. The flow of these demands is very influential for the company, especially in the supply of raw materials. UD. Sari Murni needs an alternative solution. One of the solution is by forming a system to determine the production amount of jenang or dodol, namely fuzzy Tsukamoto algorithm. It is a complete fuzzy rulebased system consists of 4 main components, namely fuzzification, rule, interference, and defuzzification. This fuzzy logic requires the user to input data in the form of variable demand, inventory, and raw materials. The Tsukamoto method in determining the amount of production of jenang or dodol at UD. Sari Murni can provide an ideal number of production prediction according to the data that has occurred. From the data testing that has been done before, the system is able to regulate the balance between the number of requests and the amount of inventory. The output from this system is the amount of production on demand. The level of success of the system in determining the amount of jenang or dodol production using the Tsukamoto fuzzy method is $90.60 \%$.
\end{abstract}

Keywords: total production, prediction of production amount determination, fuzzy Tsukamoto algorithm.

\begin{abstract}
Abstrak
UD. Sari Murni atau biasa dikenal orang dengan nama Jenang Lasimun bergerak di bidang industri olahan makanan berupa jenang atau dodol, yakni makanan yang wajib ada di acara hajatan atau sebagai oleh-oleh khas. Peran SDM di dalam usaha kecil menengah ini diharuskan untuk menggunakan sistem terkomputerisasi agar dapat memenuhi kebutuhan pasar yang semakin meningkat. Permasalahan yang dihadapi UD. Sari Murni adalah permintaan yang tidak menentu. Naik turunnya suatu permintaan sangat berpengaruh terhadap perusahaan, khususnya dalam persediaan bahan baku. UD. Sari Murni membutuhkan adanya suatu alternatif solusi yakni dengan adanya sistem penentuan jumlah produksi jenang atau dodol yang dinamakan algoritma fuzzy Tsukamoto. Ini adalah suatu sistem berbasis aturan fuzzy yang lengkap terdiri dari 4 komponen utama yaitu fuzzifikasi, rule, interferensi ,dan defuzzifikasi. Logika fuzzy ini membutuhkan input berupa variabel permintaan, persediaan, dan bahan baku. Metode Tsukamoto dalam penentuan jumlah produksi jenang atau dodol pada UD. Sari Murni dapat memberikan prediksi jumlah produksi yang ideal sesuai dari data-data yang sudah terjadi. Dari pengujian data yang telah dilakukan, sistem yang dibangun mampu mengatur keseimbangan antara jumlah permintaan dengan jumlah persediaan. Output yang dihasilkan dari sistem ini berupa jumlah produksi sesuai permintaan. Tingkat keberhasilan sistem penentuan jumlah produksi jenang atau dodol menggunakan metode fuzzy Tsukamoto adalah 90,60\%.
\end{abstract}

Kata-kata kunci: jumlah produksi, prediksi penentuan jumlah produksi, algoritma fuzzy Tsukamoto.

Diterima: 16 Januari 2019, Direvisi: 31 Januari 2021, Disetujui: 31 Januari 2021 


\section{PENDAHULUAN}

Pada saat ini hampir setiap pelaku usaha di bidang olahan produk dihadapkan pada suatu permasalahan yang sama, yaitu tingkat persaingan yang sangat kompetitif. Hal ini menjadikan setiap pelaku usaha home industri atau usaha kecil menengah (UKM) mempunyai strategi-strategi untuk menghadapi era globalisasi dan perdagangan bebas, membuat persaingan bisnis semakin pesat dan terus berkembang. UD. Sari Murni atau biasa dikenal dengan nama Jenang Pak Lasimun adalah sebuah perusahaan yang bergerak di bidang produksi jenang atau dodol. Peran SDM di dalam usaha kecil menengah ini diharuskan untuk menggunakan sistem terkomputerisasi agar dapat memenuhi kebutuhan pasar yang semakin meningkat. Hal ini diharapkan akan meningkatkan penjualan serta keuntungan bagi UD. Sari Murni (Jenang Lasimun).

Untuk mencapai tingkat keberhasilan tersebut, dibutuhkan kejelian dan ketepatan dalam bidang produksi sehingga dapat memenuhi setiap permintaan pasar yang tidak dapat diprediksi. Masalah yang dihadapi oleh UD.Sari Murni yakni jumlah produksi sehubungan dengan jumlah permintaan pasar yang naik dan turun. Maka sehubungan dengan ini, UD. Sari Murni membutuhkan adanya suatu sistem yang dapat menentukan prediksi jumlah produksi jenang atau dodol.

Salah satu metode yang dapat digunakan dalam menentukan jumlah produksi adalah metode Fuzzy Tsukamoto. Penelitian tentang penerapan Metode Tsukamoto sudah pernah dilakukan oleh (Ula 2014). Dari hasil penelitian tersebut disimpulkan bahwa metode Fuzzy Tsukamoto dapat menghasilkan kondisi optimum. Peneliti lain yang meneliti tentang sistem menggunakan metode Fuzzy Tsukamoto adalah (Ikhsan, 2014). Dengan adanya sistem tersebut, user dapat lebih mudah dalam menentukan jumlah produksi. Logika fuzzy dianggap mampu dan optimal dalam memetakan suatu input ke dalam output tanpa mengabaikan faktor-faktor pendukungnya. Berdasarkan logika fuzzy yang digunakan, nantinya akan diharapkan mampu memberikan penentuan jumlah produksi jenang atau dodol dengan adanya faktor persediaan dan permintaan yang ada.

Berdasarkan latar belakang yang telah dijelaskan di atas, maka rumusan penelitian ini adalah bagaimana memanfaatkan metode Fuzzy Tsukamoto sehingga dapat memberikan solusi dan keputusan penentuan jumlah produksi pada UD. Sari Murni. Adapun tujuan yang ingin dicapai peneliti adalah untuk mengetahui prediksi penentuan jumlah produksi barang untuk membantu pihak perusahaan UD. Sari Murni di masa yang akan datang sehingga dapat mengoptimalkan persediaan barang untuk periode selanjutnya.

\section{METODE PENELITIAN}

Metodologi yang digunakan dalam penelitian ini adalah:

1. Studi Pustaka (Library Research)

Studi Pustaka dilakukan dengan cara mempelajari teori-teori literatur dan buku-buku yang berhubungan dengan objek kajian sebagai dasar dalam penelitian ini, dengan tujuan memperoleh dasar teoritis gambaran dari apa yang dilakukan. Teori yang dipelajari yaitu: bagaimana membuat aplikasi penentuan produksi barang menggunakan logika fuzzy Tsukamoto.

2. Dokumentasi

Teknik pengumpulan data dengan menggunakan catatan yang dimiliki oleh UD. Sari Murni berupa arsip dan dokumen-dokumen.

3. Wawancara

Teknik wawancara yang dilakukan adalah bertanya langsung kepada pemilik UD. Sari Murni mengenai proses produksi dan managemen di UD. Sari Murni.

4. Observasi

Teknik pengumpulan data yang dilakukan adalah mengamati objek secara langsung di UD. Sari Murni, serta mengadakan pencatatan secara sistematis terhadap objek. Berikut adalah data yang diperoleh dari UD Sari Murni: 
TABEL 1. Data Produksi tahun 2017

\begin{tabular}{ccccc}
\hline Bulan & $\begin{array}{c}\text { Permintaan } \\
(\mathbf{k g})\end{array}$ & $\begin{array}{c}\text { Persediaan } \\
(\mathbf{K g})\end{array}$ & $\begin{array}{c}\text { Bahan Baku } \\
(\mathbf{K g})\end{array}$ & $\begin{array}{c}\text { Jumlah Produksi } \\
(\mathbf{K g})\end{array}$ \\
\hline Januari & 2760 & 2700 & 1700 & 2800 \\
Februari & 2700 & 2650 & 1785 & 2975 \\
Maret & 2890 & 2790 & 1675 & 3100 \\
April & 3200 & 2900 & 1565 & 3325 \\
Mei & 2200 & 1990 & 1675 & 2250 \\
Juni & 1390 & 1295 & 850 & 1400 \\
Juli & 3225 & 3000 & 1800 & 3500 \\
Agustus & 2955 & 2900 & 2575 & 3255 \\
September & 2565 & 1900 & 1345 & 2700 \\
Oktober & 1124 & 1050 & 765 & 1255 \\
November & 5400 & 5325 & 3400 & 5475 \\
Desember & 5325 & 5225 & 3750 & 5575 \\
\hline Jumlah & $\mathbf{3 5 7 3 4}$ & $\mathbf{3 3 7 2 5}$ & $\mathbf{2 2 8 8 5}$ & $\mathbf{3 7 6 1 0}$ \\
\hline
\end{tabular}

a. Analisis

Analisa yang dilakukan meliputi mengumpulkan data-data yang dibutuhkan dan mengolahnya sesuai syarat dan ketentuan metode fuzzy Tsukamoto.

b. Pengujian

Pengujian dilakukan dengan mencari Mean Absolute Percentage Error (MAPE). MAPE merupakan cara untuk mengukur efektifitas ketepatan peramalan (nilai dugaan model) dengan menghitung persentase rata-rata absolut kesalahan yang terjadi. MAPE secara umum dirumuskan sebagai berikut:

$$
\mathrm{MAPE}=\frac{1}{n} \sum_{t=1}^{n}\left\|\frac{Y_{t}-X_{t}}{Y_{t}}\right\| x 100 \%
$$

dengan

$Y_{t}=$ Nilai pengamatan $\mathrm{ke}-\mathrm{t}$
$X_{t}=$ Nilai peramalan pada waktu ke-t
$\mathrm{n}=$ Banyak pengamatan (Tholib 2016)

c. Implementasi

Pada tahap ini diterapkan perangkat lunak pada keadaan yang sesungguhnya dengan cara menerjemahkan perancangan berdasarkan hasil analisis dalam bahasa yang dapat dimengerti oleh mesin.

\section{HASIL}

Sebelum membuat sebuah kontruksi Fuzzy Tsukamoto dibutuhkan semesta pembicaraan terlebih dahulu. Semesta pembicaraan adalah keseluruhan nilai yang diperbolehkan untuk dioperasikan dalam suatu variabel fuzzy (Kusumadewi and Purnomo 2004). Semesta pembicara pada penelitian ini ditunjukkan pada Tabel 2.

TABEL 2. Semesta Pembicaraan

\begin{tabular}{llll}
\hline Fungsi & Variabel & Himpunan & Semesta Pembicara \\
\hline Input & Permintaan & Sedikit & $1124-2700 \mathrm{~kg}$ \\
& Sedang & $2565-3200 \mathrm{~kg}$ \\
& Banyak & $2700-5400 \mathrm{~kg}$ \\
& Persediaan & Sedikit & $1050-2650 \mathrm{~kg}$ \\
& Sedang & $1990-3000 \mathrm{~kg}$ \\
& Banyak & $2650-5325 \mathrm{~kg}$ \\
& Bahan Baku & Sedikit & $765-1675 \mathrm{~kg}$ \\
& Sedang & $1565-1800 \mathrm{~kg}$ \\
& Banyak & $1675-3750 \mathrm{~kg}$
\end{tabular}


Prediksi Jumlah Produksi Barang pada UD. Sari Murni Menggunakan Metode Fuzzy Tsukamoto

$\begin{array}{ccc}\text { Output } \quad \text { Jumlah Produksi } & \text { Sedikit } & 1255-2800 \mathrm{~kg} \\ & \text { Sedang } & 2250-3255 \mathrm{~kg} \\ & \text { Banyak } & 2800-5575 \mathrm{~kg}\end{array}$

\section{Kontruksi Fuzzy Tsukamoto}

Selanjutnya dibuat sebuah rancangan pokok dalam penyelesaian sebuah fuzzy Tsukamoto yang di dalamnya ada beberapa tahapan. Untuk lebih jelasnya berikut adalah beberapa tahapan yang dilakukan fuzzy Tsukamoto pada perancangan sistem berupa flowchart. Flowchart umum sistem ditunjukkan pada Gambar 1.

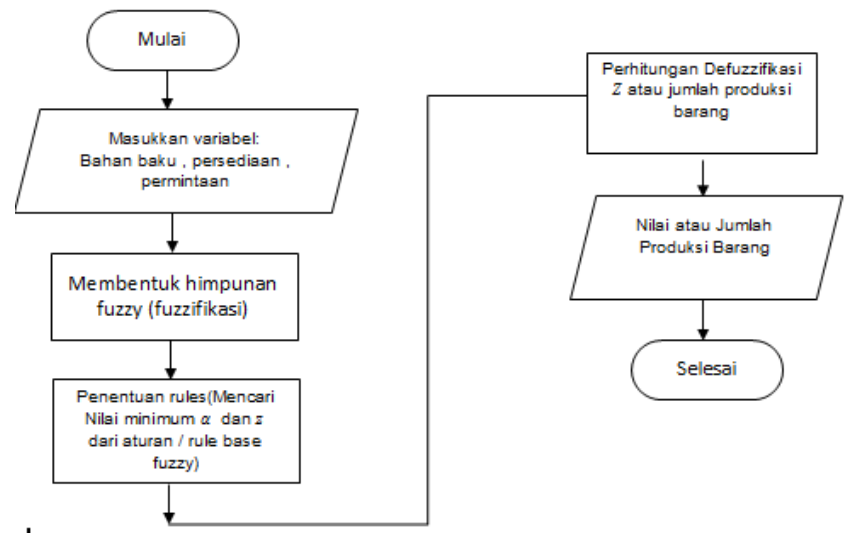

GAMBAR 1. Flowchart umum sistem

\section{Fuzzifikasi (Membentuk Himpunan Fuzzy)}

Menurut (Wang 1997), fuzzifikasi didefinisikan sebagai pemetaan dari himpunan tegas ke himpunan fuzzy. Flowchart fuzzifikasi ditunjukkan pada Gambar 2.

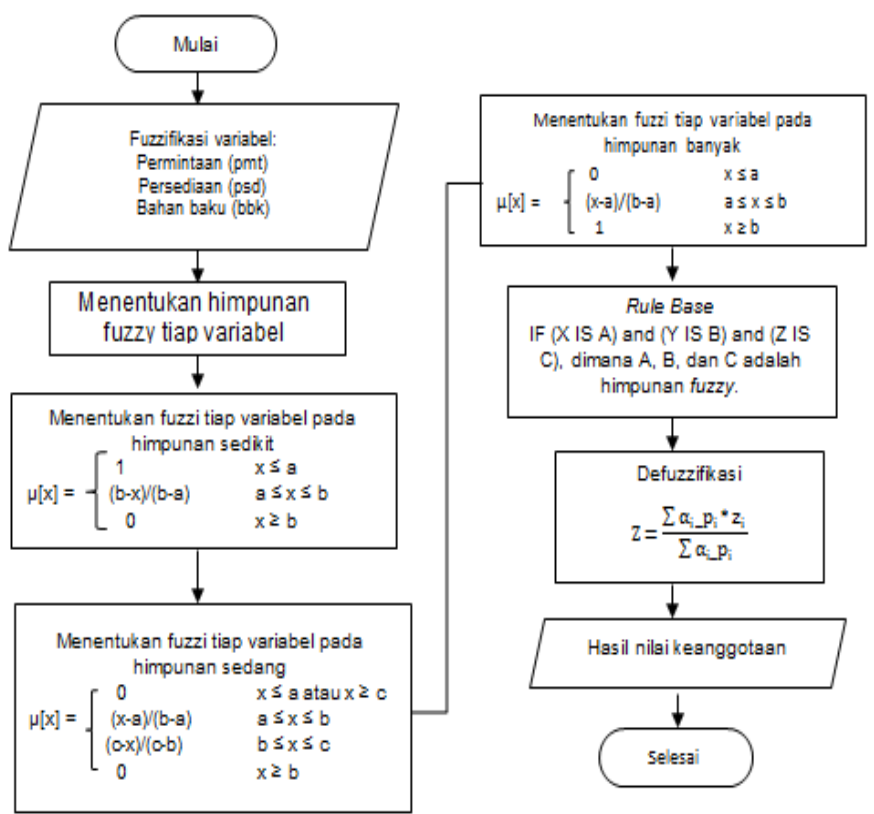

GAMBAR 2. Flowchart Fuzzifikasi 


\section{A. Fitria dan P. A. Wasna}

\section{Perancangan Inferensi Fuzzy}

Dalam perancangan inferensi fuzzy, langkah awal yang perlu dilakukan adalah pembentukan himpunan fuzzy. Variabel fuzzy diperoleh dari spesifikasi data jenang UD. Sari Murni. Penentuan range ditunjukkan pada Tabel 3 .

TABEL 3. Penentuan Range

\begin{tabular}{llc}
\hline Variabel & \multicolumn{3}{c}{ Himpunan Input } \\
\hline \multirow{2}{*}{ Permintaan } & Nama & Nilai \\
& Sedikit & $1124 \mathrm{~kg}$ \\
Persediaan & Sedang & $2700 \mathrm{~kg}$ \\
& Banyak & $5400 \mathrm{~kg}$ \\
& Sedikit & $1050 \mathrm{~kg}$ \\
Bahan Baku & Sedang & $2650 \mathrm{~kg}$ \\
& Banyak & $5325 \mathrm{~kg}$ \\
Jumlah Produksi & Sedikit & $765 \mathrm{~kg}$ \\
& Sedang & $1675 \mathrm{~kg}$ \\
& Banyak & $3750 \mathrm{~kg}$ \\
& Sedikit & $1255 \mathrm{~kg}$ \\
& Sedang & $2800 \mathrm{~kg}$ \\
& Banyak & $5575 \mathrm{~kg}$ \\
\hline
\end{tabular}

\section{Fungsi Keanggotaan}

Fungsi keanggotaan adalah suatu kurva yang menunjukkan titik-titik input data ke dalam nilai keanggotaanya yang memiliki interval antara 0 sampai 1 (Kuncahyo, Ginardi and Arieshanti 2012). Penentuan fungsi keanggotaan sesuai dengan variable-variabel pada tabel 3, ditunjukkan sebagai berikut:

1. Variabel permintaan yang terdiri dari 3 himpunan, yaitu: sedikit, sedang, banyak

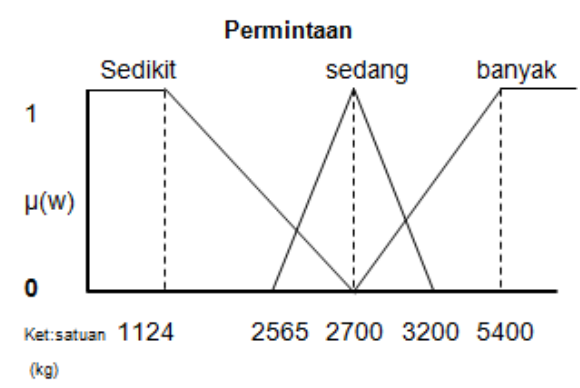

GAMBAR 3. Fungsi Keanggotaan Variabel Permintaan

Fungsi Keanggotaan:

$$
\begin{gathered}
\mu \text { sedikit }=\left\{\begin{array}{l}
1, w \leq 1124 \\
\frac{(2700-w)}{(2700-1124)}, 1124 \leq w \leq 2700 \\
0, w \geq 2700
\end{array}\right. \\
\mu \text { sedang }=\left\{\begin{array}{l}
0, w \leq 2565 \text { atau } w \geq 3000 \\
\frac{(w-2565)}{(2700-2565)}, 2565 \leq w \leq 2700 \\
\frac{(3200-w)}{(3200-2700)}, 2700 \leq w \leq 3200
\end{array}\right.
\end{gathered}
$$


Prediksi Jumlah Produksi Barang pada UD. Sari Murni Menggunakan Metode Fuzzy Tsukamoto

$$
\mu \text { banyak }=\left\{\begin{array}{c}
0, w \leq 2700 \\
\frac{(w-2700)}{(5400-2700)}, 2700 \leq w \leq 5400 \\
1, w \geq 5400
\end{array}\right.
$$

2. Variabel persediaan yang terdiri dari 3 himpunan, yaitu: sedikit, sedang, banyak persediaan

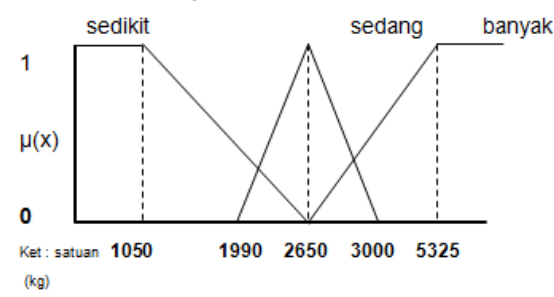

GAMBAR 4. Fungsi Keanggotaan Variabel Persediaan

Fungsi Keanggotaan:

$$
\begin{aligned}
& \mu \text { sedikit }=\left\{\begin{array}{c}
1, x \leq 1050 \\
\frac{(2650-x)}{(2650-1050)} \\
0, x \geq 2650
\end{array}, 1050 \leq x \leq 2650\right. \\
& \mu \text { sedang }=\left\{\begin{array}{c}
0, x \leq 1990 \text { atau } \mathrm{x} \geq 3000 \\
\frac{(\mathrm{x}-1990)}{(2650-1990)}, 1990 \leq x \leq 2650 \\
\frac{(3000-\mathrm{x})}{(3000-2650)}, 2650 \leq x \leq 3000
\end{array},\right. \\
& \mu \text { banyak }=\left\{\begin{array}{c}
0, x \leq 2650 \\
\frac{(\mathrm{x}-2650)}{(5325-2650)} \\
1, w \geq 5325
\end{array}, 2650 \leq w \leq 5325\right.
\end{aligned}
$$

3. Variabel bahan baku yang terdiri dari 3 himpunan, yaitu: sedikit, sedang, banyak.

$$
\text { Bahan baku }
$$

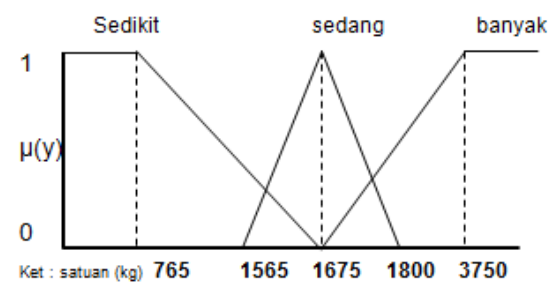

Fungsi Keanggotaan:

GAMBAR 5. Fungsi Keanggotaan Variabel Bahan Baku

$$
\begin{gathered}
\mu \text { sedikit }=\left\{\begin{array}{l}
\begin{array}{l}
1, y \leq 765 \\
\frac{(1675-y)}{(1675-765)} \\
0, y \geq 1675
\end{array}, 765 \leq y \leq 1675 \\
\mu \text { sedang }=\left\{\begin{array}{l}
\frac{0, y \leq 1565}{(y-1565)} \\
\frac{(1675-1565)}{(1800-y)} \\
(1800-1675)
\end{array}, 1675 \leq y \leq 1800\right.
\end{array}\right.
\end{gathered}
$$




$$
\mu \text { banyak }=\left\{\begin{array}{c}
0, y \leq 1675 \\
\frac{(y-1675)}{(3750-1675)} \\
1, y \geq 3750
\end{array}, 1675 \leq y \leq 3750\right.
$$

4. Variabel jumlah produksi yang terdiri dari 3 himpunan, yait : sedikit, sedang, banyak

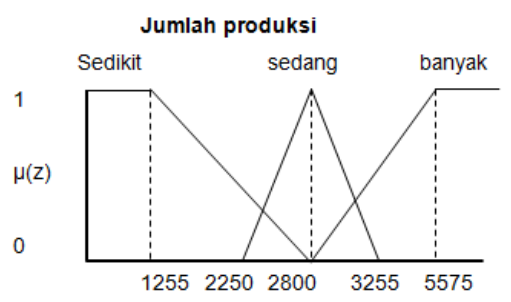

GAMBAR 6. Fungsi Keanggotaan Variabel Jumlah Produksi

Fungsi Keanggotaan:

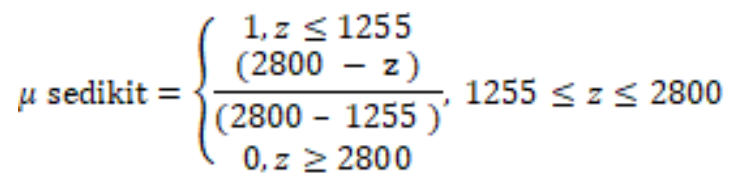

$$
\begin{aligned}
& \mu \text { sedang }=\left\{\begin{array}{c}
0, z \leq 2250 \text { atau } \mathrm{z} \geq 3255 \\
\frac{(\mathrm{z}-2250)}{(2800-2250)}, 2250 \leq z \leq 2800 \\
\frac{(3255-\mathrm{z})}{(3255-2800)}, 2800 \leq z \leq 3255
\end{array} .\right. \\
& \mu \text { banyak }=\left\{\begin{array}{c}
0, z \leq 2800 \\
\frac{(z-2800)}{(5575-2800)} \\
1, z \geq 5575
\end{array}, 2800 \leq z \leq 5575\right.
\end{aligned}
$$

\section{Pembentukan Rules}

Selanjutnya dari fuzzifikasi dilakukan inferensi fuzzy, yaitu mengaplikasikan aturan pada masukan fuzzy yang dihasilkan dalam proses fuzzifikasi. Dalam inferensi fuzzy, masukan fuzzy dihubungkan dengan suatu relasi fuzzy dengan menggunakan fungsi implikasi, yaitu IF ( $\boldsymbol{x}_{\mathbf{1}}$ is $\left.\boldsymbol{a}_{\mathbf{1}}\right)$ and $\left(\boldsymbol{x}_{2}\right.$ is $\left.\boldsymbol{a}_{2}\right)$ THEN $\mathbf{y}$ is $\mathbf{b}$. Dari fungsi implikasi tersebut akan dicari nilai $\alpha$-predikat terkecil dari tiap-tiap aturan yang ditetapkan. Dalam penentuan rules ini ada 27 aturan yang didapatkan dari metode sistem berbasis aturan yang mana kita bisa menentukan aturan dalam penentuan jumlah produksi jenang. Blok diagram ditunjukkan pada Gambar 7.

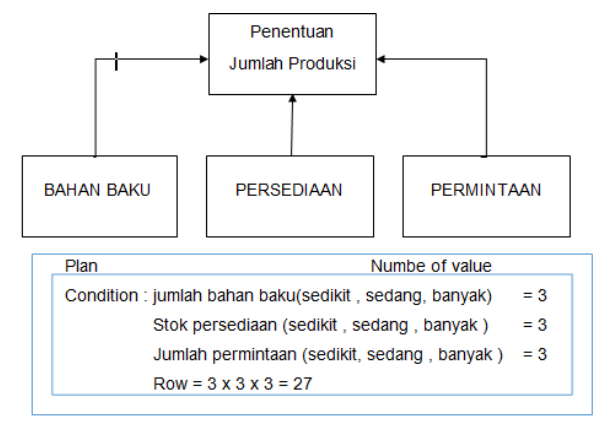

GAMBAR 7. Blok Diagram Aturan Sistem 
Berikut aturan yang digunakan dalam sistem. Aturan sistem ditunjukkan pada Tabel 4.

TABEL 4. Rules Penentuan Jumlah Produksi Jenang

\begin{tabular}{lllll}
\hline No & Permintaan & Persediaan & Bahan Baku & $\begin{array}{c}\text { Produksi } \\
\text { (Output) }\end{array}$ \\
\hline 1 & Sedikit & Sedikit & Sedikit & Sedikit \\
2 & Sedikit & Sedikit & Sedang & Sedang \\
3 & Sedikit & Sedikit & Banyak & Banyak \\
4 & Sedikit & Sedang & Sedikit & Sedikit \\
5 & Sedikit & Sedang & Sedang & Sedang \\
6 & Sedikit & Sedang & Banyak & Banyak \\
7 & Sedikit & Banyak & Sedikit & Sedikit \\
8 & Sedikit & Banyak & Sedang & Sedang \\
9 & Sedikit & Banyak & Banyak & Banyak \\
10 & Sedang & Sedikit & Sedikit & Sedikit \\
11 & Sedang & Sedikit & Sedang & Sedang \\
12 & Sedang & Sedikit & Banyak & Banyak \\
13 & Sedang & Sedang & Sedikit & Sedikit \\
14 & Sedang & Sedang & Sedang & Sedang \\
15 & Sedang & Sedang & Banyak & Banyak \\
16 & Sedang & Banyak & Sedikit & Sedikit \\
17 & Sedang & Banyak & Sedang & Sedang \\
18 & Sedang & Banyak & Banyak & Banyak \\
19 & Banyak & Sedikit & Sedikit & Sedikit \\
20 & Banyak & Sedikit & Sedang & Sedang \\
21 & Banyak & Sedikit & Banyak & Banyak \\
22 & Banyak & Sedang & Sedikit & Sedikit \\
23 & Banyak & Sedang & Sedang & Sedang \\
24 & Banyak & Sedang & Banyak & Banyak \\
25 & Banyak & Banyak & Sedikit & Sedikit \\
26 & Banyak & Banyak & Sedang & Sedang \\
27 & Banyak & Banyak & Banyak & Banyak \\
\hline & & & & \\
\hline
\end{tabular}

Tabel 4 sebagai acuan dalam penentuan fungsi implikasi untuk mencari nilai (z1, z2, $\mathrm{z} 3, \ldots \ldots \ldots . . . . \mathrm{zn})$, untuk mencari nilai $\mathrm{z}$ terlebih dahulu harus dicari nilai $\alpha$-predikat dari setiap aturan. Nilai $\alpha$-predikat dapat diperoleh dengan mencari nilai min pada setiap aturan. Berikut adalah contoh kasus dari perusahaan UD. Sari Murni. Dalam 1 bulan terakhir nilai permintaan (3125), persediaan (2890), bahan baku (1675). Dari data tersebut, berapakah jumlah produksi jenang yang harus diproduksi?

Sebelum dilakukan inferensi perlu dicari terlebih dahulu derajat keanggotaan nilai tiap variabel :

1. Variabel Permintaan

$\mu$ Sedikit $=0$

$\mu$ Sedang $=0.15$

$\mu$ Banyak $=0.85$

2. Variabel Persediaan

$\mu$ Sedikit $=0$

$\mu$ Sedang $=0.3$

$\mu$ Banyak $=0.7$

3. Variabel Bahan Baku

$\mu$ Sedikit $=0$

$\mu$ Sedang $=1$

$\mu$ Banyak $=0$

Kemudian dicari $\alpha$-predikat dan nilai z untuk setiap aturan :

[R1] IF permintaan sedikit AND persediaan sedikit AND bahan baku sedikit THEN produksi sedikit.

$\alpha$-predikat $=\min \mu$ Sedikit $(3125) ; \mu$ Sedikit $(2890) ; \mu$ Sedikit $(1675)$

$$
=\min (0 ; 0 ; 0)=0
$$


Himpunan penilaian produksi sedikit

$\mathrm{z} 1=2800$

[R2] IF permintaan sedikit AND persediaan sedikit AND bahan baku sedang THEN produksi sedang

$\alpha$ - predikat $=\min \mu$ Sedikit $(3125) ; \mu$ Sedikit $(2890) ; \mu$ Sedang $(1675)$

$$
=\min (0 ; 0 ; 1)=0
$$

Himpunan penilaian produksi sedang

$\mathrm{z}=2753$

[R3] IF permintaan sedikit AND persediaan sedikit AND bahan baku banyak THEN produksi sedikit

$\alpha$ - predikat $=\min \mu$ Sedikit $(3125) ; \mu$ Sedikit $(2890) ; \mu$ Banyak (1675)

$$
=\min (0 ; 0 ; 0)=0
$$

Himpunan penilaian maksimal

$\mathrm{z} 1=2800$

\begin{tabular}{|c|c|c|c|c|c|c|}
\hline \multirow[t]{2}{*}{ Rule } & \multicolumn{3}{|c|}{ IF } & \multirow[t]{2}{*}{$\alpha$ predikat } & \multirow[t]{2}{*}{$\mathrm{z}$} & \multirow[t]{2}{*}{ THEN } \\
\hline & Permintaan & Persediaan & $\begin{array}{c}\text { Bahan } \\
\text { Baku }\end{array}$ & & & \\
\hline R1 & 0 & 0 & 0 & 0 & 2800 & Sedikit \\
\hline $\mathrm{R} 2$ & 0 & 0 & 1 & 0 & 2753 & Sedang \\
\hline R3 & 0 & 0 & 0 & 0 & 2800 & Banyak \\
\hline $\mathrm{R} 4$ & 0 & 0.3 & 0 & 0 & 2800 & Sedikit \\
\hline R5 & 0 & 0.3 & 1 & 0 & 2753 & Sedang \\
\hline R6 & 0 & 0.3 & 0 & 0 & 2800 & Banyak \\
\hline R7 & 0 & 0.7 & 0 & 0 & 2800 & Sedikit \\
\hline $\mathrm{R} 8$ & 0 & 0.7 & 1 & 0 & 2753 & Sedang \\
\hline R9 & 0 & 0.7 & 0 & 0 & 2800 & Banyak \\
\hline $\mathrm{R} 10$ & 0.15 & 0 & 0 & 0 & 2800 & Sedikit \\
\hline $\mathrm{R} 11$ & 0.15 & 0 & 1 & 0 & 2753 & Sedang \\
\hline $\mathrm{R} 12$ & 0.15 & 0 & 0 & 0 & 2800 & Banyak \\
\hline $\mathrm{R} 13$ & 0.15 & 0.3 & 0 & 0 & 2800 & Sedikit \\
\hline R14 & 0.15 & 0.3 & 1 & 0.15 & 2760 & Sedang \\
\hline $\mathrm{R} 15$ & 0.15 & 0.3 & 0 & 0 & 2800 & Banyak \\
\hline $\mathrm{R} 16$ & 0.15 & 0.7 & 0 & 0 & 2800 & Sedikit \\
\hline $\mathrm{R} 17$ & 0.15 & 0.7 & 1 & 0.15 & 2760 & Sedang \\
\hline R18 & 0.15 & 0.7 & 0 & 0 & 2800 & Banyak \\
\hline R19 & 0.85 & 0 & 0 & 0 & 2800 & Sedikit \\
\hline R20 & 0.85 & 0 & 1 & 0 & 2753 & Sedang \\
\hline R21 & 0.85 & 0 & 0 & 0 & 2800 & Banyak \\
\hline R22 & 0.85 & 0.3 & 0 & 0 & 2800 & Sedikit \\
\hline R23 & 0.85 & 0.3 & 1 & 0.3 & 2767 & sedang \\
\hline R24 & 0.85 & 0.3 & 0 & 0 & 2800 & banyak \\
\hline $\mathrm{R} 25$ & 0.85 & 0.7 & 0 & 0 & 2800 & Sedikit \\
\hline R26 & 0.85 & 0.7 & 1 & 0.7 & 2786 & Sedang \\
\hline R27 & 0.85 & 0.7 & 0 & 0 & 2800 & Banyak \\
\hline
\end{tabular}

TABEL 5. Nilai $z$

Proses terakhir adalah defuzzifikasi, yaitu mengubah fuzzy output menjadi crips value sehingga mendapatkan nilai output sistem. Jadi, setelah didapatkan nilai $\alpha$-predikat dari setiap 
aturan, dilakukan proses defuzzifikasi untuk mendapatkan nilai z akhir dengan menggunakan aturan rata-rata terbobot seperti rumus di bawah ini ;

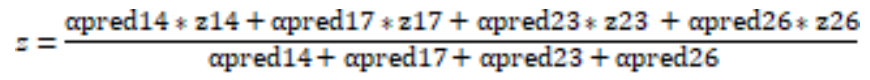

$\mathrm{z}=2775$ (Kusumadewi and Purnomo 2004)

Dari studi kasus yang telah dipaparkan, diperoleh hasil penentuan jumlah produksi sebanyak $2775 \mathrm{~kg}$ untuk mendapatkan hasil produksi optimasi sesuai dengan variabel lainnya yang ada pada UD.Sari Murni.

\section{IMPLEMENTASI}

Tahap implementasi merupakan tahap mewujudkan hasil perancangan menjadi sebuah program aplikasi yang dapat dioperasikan demi mencapai hasil yang sesuai dengan hasil perancangan. Setelah melakukan tahap perancangan sistem, tindakan selanjutnya yang dilakukan adalah penerapan hasil perangkat lunak tersebut sebagai berikut:

a. Tampilan awal program yakni sebagai berikut:

Penentuan Jumlah Produksi

Barang Pada UD. SARI MURNI

Menggunakan Fuzzy Tsukamoto

GAMBAR 8. Tampilan Awal Menu Program

Keterangan:

Pada tampilan awal program terdapat menu antara lain

1. Home

Berisi judul pembuatan aplikasi / project

2. Produksi

Berisi form untuk penambahan data produksi per bulan.

3. Rule

Berisi form tentang aturan rule dari metode Fuzzy Tsukamoto

4. Prediksi

Berisi form prediksi

5. About

Berisi tentang identitas penulis.

b. Form Produksi digunakan untuk input data produksi perusahaan per bulannya dan langsung tersimpan otomatis dalam tabel database. Berikut tampilan form tambah data produksi.

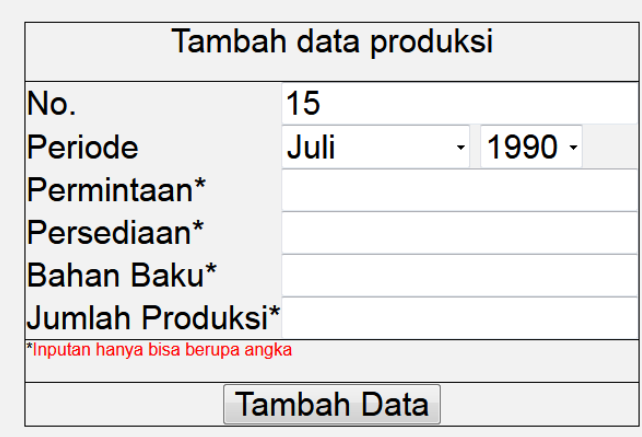

GAMBAR 9. Form Tambah Data Produksi 
Data Produksi Perbulan

\begin{tabular}{|c|l|c|c|c|c|}
\hline No & \multicolumn{1}{|c|}{ Periode } & Permintaan & Persediaan & Bahan Baku & $\begin{array}{c}\text { Jumlah } \\
\text { Produksi }\end{array}$ \\
\hline 1 & Januari 2017 & 2760 & 2700 & 1700 & 2800 \\
\hline 2 & Februari 2017 & 2700 & 2650 & 1785 & 2975 \\
\hline 3 & Maret 2017 & 2890 & 2790 & 1675 & 3100 \\
\hline 4 & April 2017 & 3200 & 2900 & 1565 & 3325 \\
\hline 5 & Mei 2017 & 2200 & 1990 & 1675 & 2250 \\
\hline 6 & Juni 2017 & 1390 & 1295 & 850 & 1400 \\
\hline 7 & Juli 2017 & 3225 & 3000 & 1800 & 3500 \\
\hline 8 & Agustus 2017 & 2955 & 2900 & 2575 & 3255 \\
\hline 9 & September 2017 & 2565 & 1900 & 1345 & 2700 \\
\hline 10 & Oktober 2017 & 1124 & 1050 & 765 & 1255 \\
\hline 11 & November 2017 & 5400 & 5325 & 3400 & 5475 \\
\hline 12 & Desember 2017 & 5325 & 5225 & 3750 & 5575 \\
\hline 13 & januari & 0 & 0 & 0 & 0 \\
\hline 14 & Juli 1990 & 0 & 0 & 0 & 0 \\
\hline
\end{tabular}

GAMBAR 10. Form Hasil Simpan Data Produksi

c. Dalam proses perhitungan penentuan range terdapat input pada kriteria, yaitu: jumlah permintaan, jumlah persediaan, dan jumlah bahan baku. Berikut tampilan program dan listing kode program dalam prosesnya:

\begin{tabular}{l} 
Input Data Yang Akan Diprediksi \\
\hline Permintaan \\
Persediaan \\
Bahan Baku \\
\hline Inputan hanya bisa berupa angka \\
\hline \\
OK \\
\hline
\end{tabular}

GAMBAR 11. Form Input Data yang akan Diprediksi

\begin{tabular}{|c|c|c|}
\hline \multicolumn{3}{|c|}{ Penentuan Range } \\
\hline & Sedikit : 0 & - \\
\hline \multirow{2}{*}{ 1Permintaan } & Sedang: & - \\
\hline & Banyak: & -5400 \\
\hline \multirow{3}{*}{ 2Persediaan } & Sedikit : 0 & - \\
\hline & Sedang: & - \\
\hline & Banyak: & -5325 \\
\hline & Sedikit : 0 & - \\
\hline \multirow{2}{*}{ 3Bahan BakL } & uSedang: & - \\
\hline & Banyak: & -3750 \\
\hline \multirow{3}{*}{ 4Produksi } & Sedikit : 0 & - \\
\hline & Sedang: & - \\
\hline & Banyak: & -5575 \\
\hline \multicolumn{3}{|c|}{ 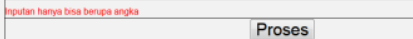 } \\
\hline
\end{tabular}

GAMBAR 12. Form Penentuan Range

\begin{tabular}{|c|c|}
\hline \multicolumn{2}{|r|}{ Himpunan Fuzzy } \\
\hline Permintaan & \begin{tabular}{|l|l|} 
Sedikit $1124-27000$ \\
Sedang $2565-32000.15$ \\
Banyak $2700-54000.85$ \\
\end{tabular} \\
\hline Persediaan & \begin{tabular}{|l|l|} 
Sedikit 1050 - 26500 \\
Sedang $1990-30000.31$ \\
Banyak $2650-53250.69$ \\
\end{tabular} \\
\hline Bahan Baku & \begin{tabular}{|l|} 
Sedikit $765-16750$ \\
Sedang $1565-18001$ \\
Banyak $1675-37500$
\end{tabular} \\
\hline
\end{tabular}

GAMBAR 13. Form Hasil Perhitungan Himpunan Fuzzy

d. Langkah selanjunya adalah mencari $\alpha$-predikat dan nilai $z$ untuk setiap aturan. Berikut tampilan program dan listing kode program dalam prosesnya: 


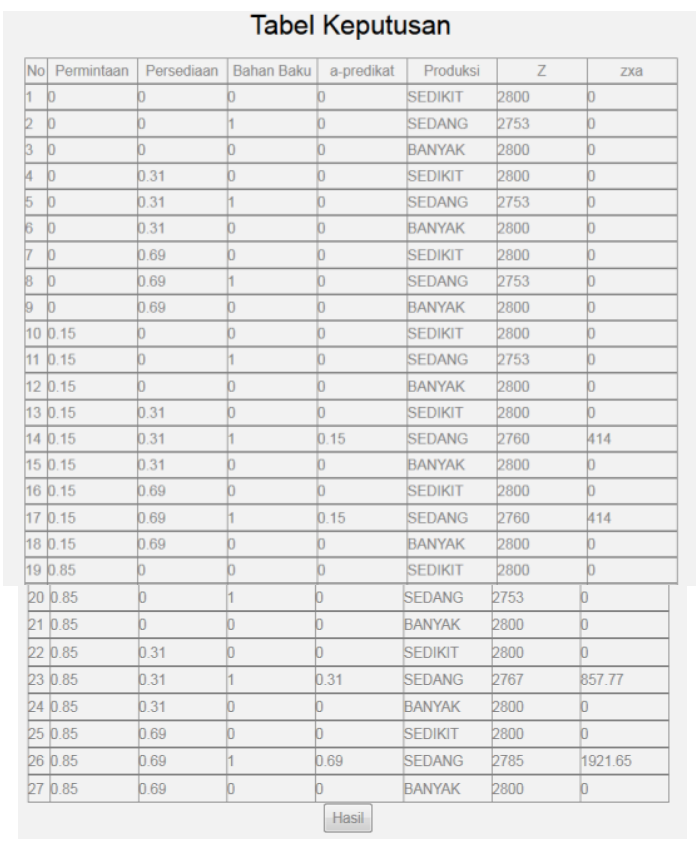

GAMBAR 14. Form Hasil Berupa Tabel Keputusan

Langkah terakhir adalah proses hasil prediksi. Berikut tampilan program dalam prosesnya :

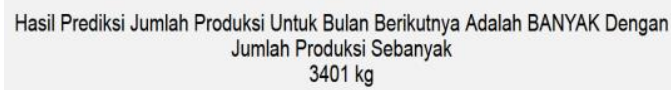

GAMBAR 15. Form Hasil Prediksi dengan Metode Fuzzy Tsukamoto

\section{PENGUJIAN SISTEM}

Berikut adalah perbandingan jumlah produksi dari data pada UD. Sari Murni dan jumlah produksi dari hasil perhitungan menggunakan Fuzzy Tsukamoto berserta tabel persentase errornya.

TABEL 6. APE

\begin{tabular}{lccc}
\hline Bulan & $\begin{array}{c}\text { Hasil Produksi } \\
\text { Sebenarnya }\end{array}$ & $\begin{array}{c}\text { Hasil Prediksi } \\
\text { Tsukamoto }\end{array}$ & APE \\
\hline Januari & 2800 & 2782 & $0,64 \%$ \\
Februari & 2975 & 2811 & $5,51 \%$ \\
Maret & 3100 & 2775 & $10,48 \%$ \\
April & 3325 & 2615 & $21,35 \%$ \\
Mei & 2250 & 2768 & $23,02 \%$ \\
Juni & 1400 & 1518 & $8,43 \%$ \\
Juli & 3500 & 2967 & $15,23 \%$ \\
Agustus & 3255 & 3837 & $17,88 \%$ \\
September & 2700 & 2661 & $1,44 \%$ \\
Oktober & 1255 & 1255 & $0,00 \%$ \\
November & 5475 & 5103 & $6,79 \%$ \\
Desember & 5575 & 5464 & $1,99 \%$ \\
\hline
\end{tabular}

Dari hasil pengujian tersebut dapat diketahui MAPE dari peramalan jumlah produksi di UD. Sari Murni adalah 9,4\%. Jadi, tingkat akurasi sistem penentuan prediksi jumlah produksi jenang atau dodol menggunakan metode fuzzy Tsukamoto adalah $100 \%-9,4 \%=90,60 \%$. 


\section{KESIMPULAN}

1. Perancangan sistem penentuan jumlah produksi ini dibuat sebagai alat bantu untuk penentuan produksi jenang atau dodol satu bulan ke depan berdasarkan data-data yang diberikan berupa data permintaan, persediaan, dan bahan baku pada tahun 2017, dengan menggunakan logika fuzzy Tsukamoto.

2. Tingkat keberhasilan sistem penentuan jumlah produksi jenang atau dodol sari murni menggunakan metode fuzzy tsukamoto adalah $90,60 \%$.

\section{DAFTAR ACUAN}

Ikhsan, F. K. 2014, 'Penerapan Fuzzy Tsukamoto Dalam Sistem', Proseding Seminar Bisnis dan Teknologi, pp. 15-16.

Kuncahyo, B., Ginardi, R. and Arieshanti 2012, Penerapan Metode Adaptive Neuro-Fuzzy Inference System untuk Meprediksi Nilai Post Test Mahasiswa. ITS Surabaya.

Kusumadewi, S. and Purnomo, H. 2004, Aplikasi Logika Fuzzy untuk Pendukung Keputusan. Pertama. Yogyakarta: Graha Ilmu.

Tholib 2016, Peramalan Penjualan dalam Rangka Perencanaab Produksi Pada Perusahaan Furniture (Studi Kasus CV. Budi Luhur Sidoarjo). Institut Teknologi Sepuluh Nopember Surabaya.

Ula, M. 2014, 'Implementasi Logika Fuzzy Dalam Optimasi Jumlah Pengadaan Barang Menggunakan Metode Tsukamoto (Studi Kasus: Toko Kain My Text)', Jurnal ECOTIPE, 1(2). Available

http://download.portalgaruda.org/article.php?article=279221\&val=5439\&title=Implementasi Logika Fuzzy Dalam Optimasi Jumlah Pengadaan Barang Menggunakan Metode Tsukamoto.

Wang, L. 1997, A Course in Fuzzy Systems and Control. New Jersey: Prentice-Hall, Inc. 